\title{
The determinants of male retirement in urban Brazil
}

Bernardo Lanqa Queiroz. Cedeplar/UFMG

\section{Key words}

retirement, labor force participation,

social security systems.

JEL Classification J26.

\section{Palauras-chave}

aposentadoria, participação no mercado de trabalho, sistema de seguridade social.

Classificação JEL J26.

\section{Abstract}

I use matched and unmatched PME data to study the determinants of male's retirement over the past two decades. The PME is a very rich source of data, although not very used. The matched data consists of a series of short panel data constructed by matching individual records across adjacent years of the PME. Some patterns I find are not surprising. For example, probability of being retired increases monotonically with age, and the strong dependence of labor transition on other individual characteristics such as education.

Some other patterns are more interesting and surprising. The labor force participation rates of older workers in the main metropolitan areas are lower than what is observed in the rest of the country. The main explanation is that workers in the main metropolitan areas had earlier enrollment into the system and they also have better access to early retirement benefits. I also observed an inverse U-shaped relation between education and retirement. Less and more educated workers have similar retirement patterns during the period studied. Last, I find that more educated workers, and those in the formal sector, have higher retirement probabilities than less educated and those in the informal labor market.

\section{Resumo}

Eu uso dados longitudinais e de periodo da Pesquisa Mensal de Emprego (PME) para investigar os determinantes da aposentadoria masculina nas duas últimas décadas. A PME é uma fonte de dados muito rica, porém pouco utilizada. Os dados longitudinais foram construidos pareando informações individuais de anos adjacentes da PME. Eu encontrei alguns padrões de aposentadoria pouco surpreendentes. Por exemplo, a probabilidade de a pessoa ser aposentada aumenta com a idade e há uma grande dependência da transição dos indivíduos para a aposentadoria em características pessoais como a educação. Por outro lado, alguns padrões de aposentadoria são interessantes e surpreendentes. $A$ taxa de participação dos trabalhadores idosos nas áreas metropolitanas é mais baixa do que o observado nas demais regiões do país. A principal explicação é que esses trabalhadores contribuem para o sistema previdenciário há mais tempo e tem fácil acesso aos beneficios por tempo de serviç. Eu também observo uma relação de U invertido entre educação e probabilidade de aposentadoria. Os trabalhadores com mais e menos anos de educação formal têm padrões bastante similares de aposentadoria. Por último, eu mostro que os trabalhadores mais educados e aqueles no setor formal têm maior probabilidade de aposentadoria do que os trabalhadores do setor informal e com menos anos de estudo. 


\section{1_Introduction}

I use matched and unmatched Pesquisa Mensal de Emprego (PME) [Monthly Employment Survey] to study the determinants of male retirement in metropolitan Brazil over the past two decades. My primary interest is to describe the most interesting aspects of male retirement behavior over a relatively long period of time, to develop stylized facts that will help guide future research on this topic, and by using micro-data to consider individual attributes that may affect retirement decisions. These data do not show any specific time trend. I interpret this result as an indication that the reforms of the 1990s did not affect retirement of workers in the metropolitan areas. Also, I concentrated on transitions out of the labor force, I am not capturing those who collect benefits but remain working. Liberato (2003) identifies an increase in the labor force participation of workers who collected pension benefits in the 1990s.

The PME is a very rich source of information to study retirement trends, although not widely used. The matched sample consists of a series of short panel data constructed by matching individual records across adjacent years of the PME.
The structure of that data provides me with the opportunity to study the determinants of retirement behavior over time and for different cohorts. The use of the matched data is one of the main contributions of this paper.

The data cover a period of important changes in the labor market and in the public pension system (1984-1999). The pension program was expended in 1988 to cover most of the excluded rural groups and to establish the minimum wage as the minimum benefit and as the benefit adjustment index. In 1998, the Congress approved a new methodology to calculate pension benefits aiming to reduce incentives to early retirement. The system has been characterized by high coverage and low contribution rates. In the past two decades, for the whole country, benefits have increased for all age groups. At the same time, contribution rates have declined dramatically. There was not a significant fall in the labor force participation of older workers (aged 65 and above) from 1984 to 1999 which remains around $30 \%$. An important aspect of the labor market is the decline in the share of the labor force in the formal sector (formal documentation), which has declined from $70 \%$ in the 
early 1980 s to $60 \%$ in 2000 , which helps to explain the decline in contribution rates (Turra and Queiroz, 2005).

The remainder of the paper is organized as follows. The next section briefly reviews the literature on the topic. Section 3 provides a short discussion about the public pension system and the labor market in Brazil. Section 4 presents the data and some methodological considerations on estimating the models. Section 5 and Section 6 present the results for the unmatched and matched sample. Section 7 presents a summary of the main results and provides a discussion of the potential limitations of my analysis.

\section{2_Related Literature}

There is widespread concern about how population aging affects macroeconomic variables, and the public sector fiscal balance. The rapidly aging population presents one of the greatest public policy challenges in Brazil. A second related question is how the provision of social security benefits affects the retirement behavior of older workers (Wise, 2004). The literature on the determinants of male retirement in developed countries is extensive
[Gruber and Wise (1999, 2002); Costa (1998)]. The main explanation for early retirement in developed countries is the existence of generous pension programs (Gruber and Wise, 1999), and increase in income and wealth of workers (Costa, 1998).

Several studies on the US show the impact of pension regulations, income growth and behavior on labor force participation rates. Hurd (1990) shows the retirement peak at age 62 after the introduction of early retirement provisions in the 1960s. However, Krueger and Pischke (1992) find little empirical evidence linking changes in social security wealth and retirement behavior of older workers. The authors argue that the reduction in wealth did not affect downward trend in labor force participation. In other countries, the effects of pension provisions are much larger than in the US. Borsch-Supan (2000) analyzes Germany and other OECD countries and finds large disincentives to work in the public pension programs. Baker, Gruber and Milligan (2003) find that the Canadian pension program has significant impacts on retirement, and that public policy can create incentives for workers to stay in the labor force 
longer. In a different perspective, Profeta (2002) shows that the demographic variables are the main determinant of the size of the public pension programs, and of the retirement policies in a series of OECD countries.

Despite unabated interest among researchers in issues pertaining to the impact of pension programs and economic development on retirement decision, little is known about these issues in emerging economies. Brazil is one example of an important context for developing linkages between pension benefits provision and retirement behavior. Compared to other emerging economies, Brazil differs in that it combines a relatively large pension program with a rapidly aging population and rapidly declining labor force participation of older workers (Turra and Queiroz, 2005). While the elderly (65 and above) represented 8\% of the Brazilian population in 2000, social security and other forms of elderly support corresponded to $12.4 \%$ of the GDP. The age profile of labor force has also changed dramatically. In 2000 only $30 \%$ of the population 65 and above were in the labor force compared to more than $60 \%$ in 1950 .
Despite the growing interest, I am not aware of many studies aiming to examine the determinants of male retirement in Brazil. There are three main areas of research on the Brazilian pension system. The first analyzes the idiosyncrasies of the pension system and its impacts on the society. Alem, Pastoriza and Giambiagi (1998) focus on the negative effects of the length of service retirement benefit. The authors estimate the implicit subsidy of some groups with special retirement rules and find that in some cases the subsidy is as high as $50 \%$ of the benefits. Silva Leme and Málaga (2001) study the impacts of the social security rules on investments in human capital and duration of labor force participation in comparison with a capitalization regime. They find that the pension scheme does not induce further investments in human capital due to the provision of pension benefits at fairly young ages. Legrand (1995) uses 1980 census data to study effects of the social security system and of other variables on men's retirement behavior in Brazil. The results indicate that the system has strong effects on retirement.

Self-employed and employers have 
$\cdots \cdots \cdots \cdot \ldots$

1 Based on census data,

I calculated that $95 \%$ of the population age $10-14$ years was in school compared to $54 \%$ in 1960 . lower retirement propensities.

Education and high levels of income are associated with lower retirement rates.

Carvalho-Filho (1999) shows that the social security reform of 1988 impacted the labor supply of rural workers. The author finds that rural workers leave the labor force as soon as pension benefits become available.

The second field of research studies the impacts of social security on reducing income inequality and reducing poverty levels in some regions of the country. This field concludes that the Brazilian pension system has played its social role. It has elevated average income, especially for the rural population and it guarantees income for the elderly and their family members in urban areas. These two features have resulted in a reduction of poverty levels in the country (Barros, Mendonça and Santos, 1999; Camargo, 2004). The last field focuses on understanding the evolution of the components related to the expenditures, and the sustainability of the program (e.g. deficit and support ratio). This research finds that expenditures, under current conditions, will increase faster than contributions, creating more threats to the system's sustainability (Ornelas and Vieira, 1999; Giambiagi and Alem, 1997; Giambiagi and Castro, 2003). Turra and Queiroz (2005) show how the absence of appropriate policies mitigates temporary benefits of population change, and aggravates the effects of population aging on the social security program.

\section{3_Background}

\section{1_ Trends in Labor \\ Force Participation and Retirement}

The trend in labor force participation for Brazilian male workers shows significant changes in the last decades. It is clear that the length of working life was reduced over time. Labor force participation rates of young individuals have declined because of the increase in educational attainment. ${ }^{1}$ The rates have also declined for older workers.

In 1950 almost $90 \%$ of the population aged sixty to sixty-four years were in the labor force; this number has declined to $65 \%$ in 2000 . The same rate of decline is observed for younger old workers. The fall in economic participation is even greater for older workers. The labor force participation rates for those above sixty-five years of age was 30\% in 2000 compared to over 60\% in 1950 (Figure 1). 
Figure 1_ Labor Force Participation Rates, Males, Brazil, 1950-2000

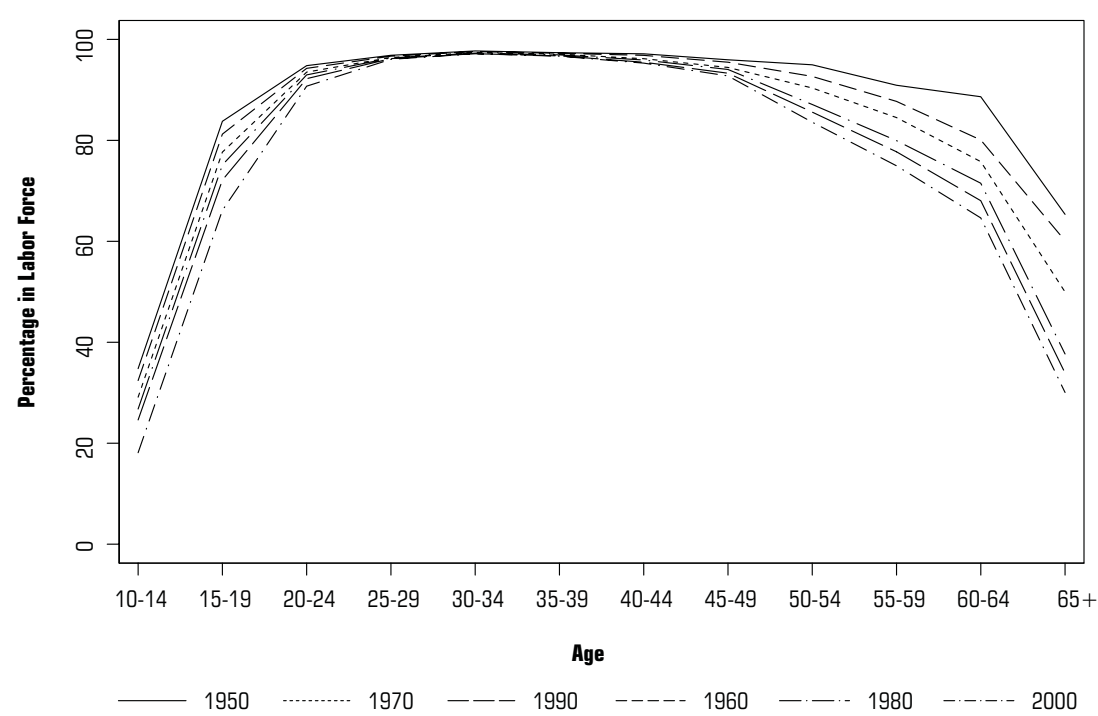

Source: International Labour Organization Database, 2005.

Labor force participation rates fell for workers of different socioeconomic backgrounds. I use years of schooling as a proxy for socioeconomic status and estimate participation rates using census data from 1960 to 2000 by four different levels of education: 0 to 4,5 to 8,9 to 11 and 12 and more years of schooling. In 2000 , participation of workers aged 60-64 and 65-69 years old, for all levels of education, intersect at the same levels around $40 \%$. For older workers, those above 70 years of age, the rates converge at lower levels around 20\% participation rates. This effect reflects the increase in the coverage of the social security system in the country, a move away from agriculture work and increase in levels of income of the older population in the past half-century.

I use the long-term information on labor force participation to study trends in retirement age. I use Brazilian census micro-data from 1960 to 2000 to estimate median retirement age for males. I estimate it as the youngest age in which less than $50 \%$ of the 
2 I estimate average retirement ages for Brazil using Sveinbjorn and Scarpetta (1998) methods. The average retirement age in 1950 was 60.17 and fell to 57.83 in 2000 . population is in the labor force (Burtless and Quinn, 2001). Following this definition, the retirement age for males declined from 69 years in 1960 to 63 years in 2000, an average of 1.5 years per decade. Trends in early retirement have occurred at the same time life expectancy is increasing. From 1960 to 2000 life expectancy at age 65 rose from 12.01 years to 14.06 , an average increase of 0.51 years per decade. These two events combined imply an increase in the percentage of one's life spent in retirement.

Table 1 shows median retirement ages for a series of countries. The average retirement age in the United States fell from 74 years in 1910 to 63 years in 2000, a drop of 1.2 years per decade (Burtless and Quinn, 2001). In the same period covered by the Brazilian data, the decline in the average retirement age in the U.S.A slowed down or even reversed. During this period the average age declined 0.75 per decade, from 66 years in 1960 to 63 years in 2000 (Burtless and Quinn, 2001). The trend toward early retirement is a common feature of the labor market in developed nations. Sveinbjorn and Scarpetta (1998) estimate average retirement ages for a series of OECD countries based on survey data on determinants of retirement. They estimate retirement ages from 1950 to 1995 and observed a steady decline in retirement ages over time. The average retirement age for men dropped from about 65 years in 1950 to around 60 years in $1995 .^{2}$

Table 1_Median retirement ages, males, 1960-2000

\begin{tabular}{|c|c|c|c|c|c|c|}
\hline Year & Brazil & USA & Italy & Germany & Japan & Netherlands \\
\hline 1960 & 69 & 66 & 64,5 & 65,2 & 67,2 & 66,1 \\
\hline 1970 & 65 & 65 & 62,6 & 65,3 & 67,7 & 63,8 \\
\hline 1980 & 65 & 64 & 61,6 & 62,2 & 67,2 & 61,4 \\
\hline 1990 & 65 & 63 & 60,9 & 60,3 & 66,5 & 59,3 \\
\hline 2000 & 63 & 63 & 60,6 & 60,5 & 66,5 & 58,8 \\
\hline
\end{tabular}

Source: IPUMS (2005) for Brazil, Burtless and Quinn (2001) for the US, and Sveinbjorn and Scarpetta (1998) for Italy, Germany, the Netherlands and Japan. 


\section{2_ The Social Security System in Brazil}

The pension system in Brazil consists of three main segments: the general system (private workers), the civil servants system, and the other general private funded systems. Most pension system are based on the PAYGO scheme (Bonturi, 2002). The country has also a large non-contributory system with means-tested eligibility that provides benefits for low-income elderly. ${ }^{3}$

The Social Security system for private workers (general system) is an unfunded defined-benefit program. There is still debate regarding when it began. In 1888 some measures were taken to provide pension benefits to postal workers and employees of the national press. In the following years, retirement benefits were extended to railroad workers, employees of the Ministry of Finance, the Mint and the armed forces. In 1923, the Congress approved the Lei Eloi Chaves (legislation) to regulate social security for both civil servants and private sector workers. This law decentralized the pension system, as each company was responsible for its own employees. The first reform happened in 1933 when the pension funds became structured by professional categories (Leite, 1983). The general pension system was centralized only in 1966, when the House of Representatives approved the Social Security Ordinary Law. The National Social Security Administration, INPS, incorporated all the revenues and expenditures from sector-specific programs as well as its assets and liabilities. Another major change during this time was in the scheme of the program, which changed from a capitalization system to PAYGO (Leite, 1983).

The last major reform occurred with the 1988 Constitution, which extended mandatory social security coverage to most of the excluded groups, including rural workers, without requiring equivalent increases in revenues from contributions. Other measures also made the system more generous than before: establishing the minimum wage as the lowest benefit paid by the system, indexing all pensions to the minimum wage, and reducing minimum retirement age (Stephanes, 1998).

Until 1998, the system granted full pension benefits to all workers who had contributed for 10 years to the system, had reached normal retirement age through the Old-Age Pension Benefit ( 65 for men and 60 for women), or could prove that they had been working for a certain number of years with the Length of Service Pension
Public expenditures on social security benefits and other forms of elderly support amount to $12 \%$ of GDP (Brazil, 2003). 
$\cdots \ldots \ldots \ldots$

4 In recent years, the system has been facing budget shortfalls, which have gradually increased after the new regulations were implemented in the early 1990s. In 1996, the deficit was equal to $0.1 \%$ but increased to $1.7 \%$ in 2004 . The implicit debt, a long term measure of the system's financial adequacy, is also large and amounts to about $200 \%$ of the GDP (Bravo and Uthoff, 1998).
Benefit (35 for men and 30 for women, but without requirement of contribution for the same period of time). In addition, special retirement schemes existed that granted proportional retirement benefits for individuals who had worked for 30 and 25 years, for men and women respectively. The social security system computes the benefits based on the last 36 months of activity (Brasil, 2002).

The level of benefits is relatively high, old-age benefits recipients receive, on average, 3 times the minimum wage, and the length of service benefits is 2.5 times higher than the old-age benefits. ${ }^{4}$

Figure 2 reveals important trends over the last two decades. The volume of social security benefits paid has increased for all age groups. At age 50, for example, about $20 \%$ of the population received benefits in 2002 compared to $17 \%$ in the early $1980 \mathrm{~s}$. At the same time, taxpayer rates have declined for both men and women. The number of men making social security contributions fell from 65\% in 1980 to $50 \%$ in 2002. Similar results are true for women in spite of recent increases in labor force participation (Turra and Queiroz, 2005).

Alongside the general pension system, civil servants have their own pension program, which is also an unfunded PAYGO defined benefit program. Although smaller in absolute numbers when compared to the general program, expenditures with the civil servants are large, reaching 4.7 percent of the GDP in 2002 (Bonturi, 2002). The program is a complex chain of federal, state and local systems, including special programs for different civil servants categories. Benefits are more generous in the civil servant program: replacement rates are higher and time of contribution to receive full benefits is shorter (Medici, 2002).

\section{4_Data and Methods}

\section{1_Pesquisa Mensal de Emprego PME}

The Monthly Employment Survey PME is conducted by interviewing approximately 30,000 households from six metropolitan regions: Salvador, Recife, Belo Horizonte, Porto Alegre, Rio de Janeiro and Sao Paulo. These regions are highly representative of urban Brazil in terms of population, regions and labor market. The questionnaire includes questions related to the demographic characteristics of the members of the household above age 10 . 
Figure 2_ Percentage of males and females receiving pension benefits and paying social security taxes, Brazil, 1980-2002 (selected years)
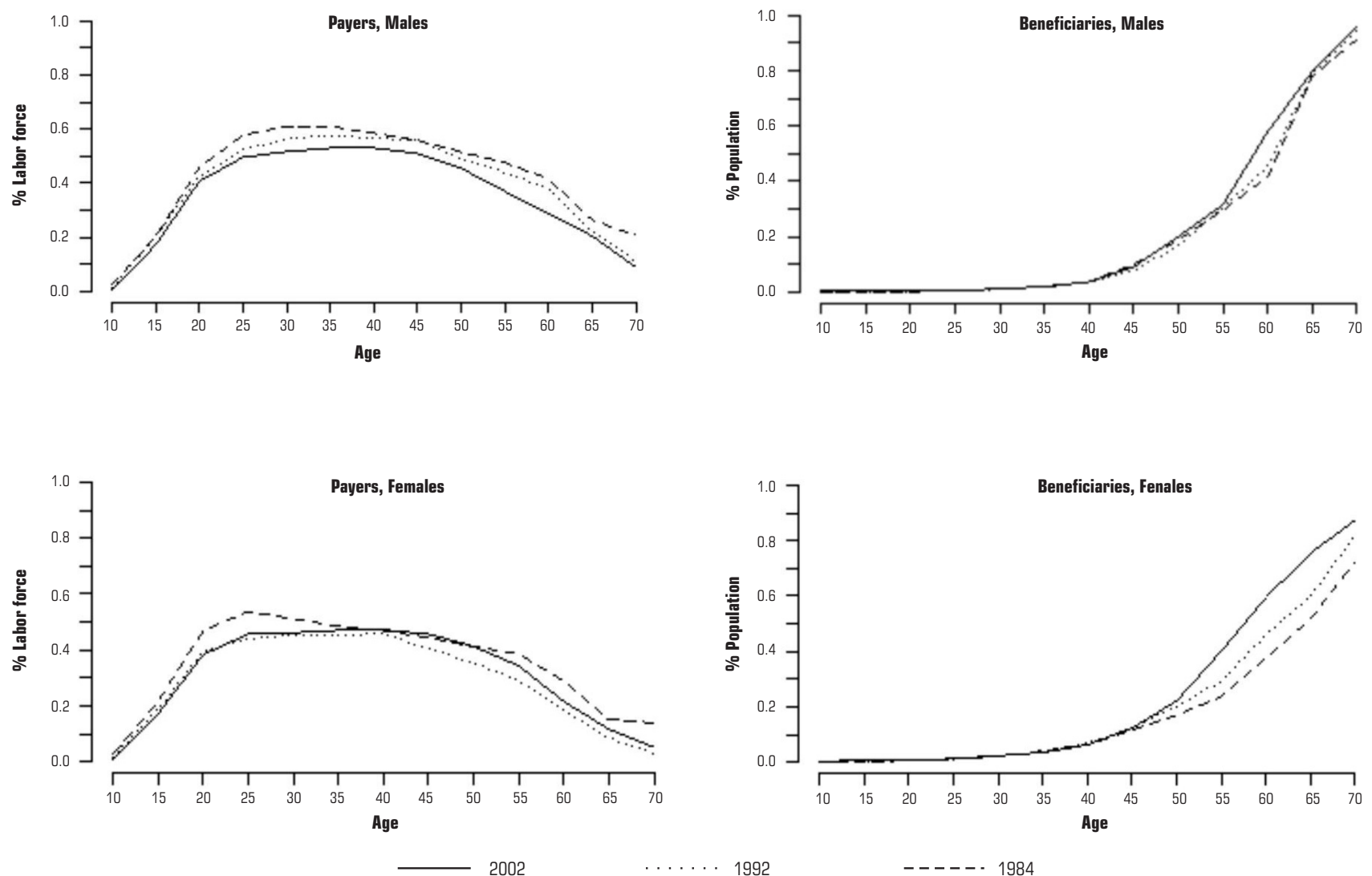

1992

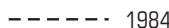

Source: Pesquisa Nacional por Amostra Domiciliar (PNAD), 1984, 1992 e 2002. 
5 Peracchi and Welch (1994) studied labor market transitions in the US using the CPS and discuss the characteristics of the survey.

6 For instance, 1984 to 1985 and 1986 to 1987 , and not 1984 to 1985,1985 to 1986 and 1986 to 1987 .
It includes information on age, sex, education, activity in week of reference, number of hours worked, income, and sector of activity, and others related to unemployment and job search. The PME considers as part of the labor force the population aged 15 and above capable of working and either working or looking for work during the week of reference. The employed population also includes individuals who were performing non-gainful activities during the week of reference. The questionnaires are, however, consistent over time and allow for interesting inter-temporal analysis.

The data collection is done using a rotation panel scheme very similar to the United States Current Population Survey (CPS). ${ }^{5}$ Table 2 illustrates the structure of the interviews in the PME. Each household participates in the survey for four consecutive months, does not participate for eight months and then joins the survey again for additional four consecutive months. The structure implies that from month to month $75 \%$ of households stay in the sample and for every pair of years, in the same month, the sample is the same. A disadvantage of the PME is that I can only analyze transitions over a one-year period. In my analysis I only use the household's first and last interviews. The major shortcoming of this approach is that I can only focus on labor market transitions of every other pair of years instead of every pair of years. ${ }^{6}$

I cannot match households in the PME using the household identification number and the month of the survey. The matching process using these two unique variables is not perfect because the unit of analysis is the household and not the person. Therefore, if all members of the household move out between the period of the survey, and new members move to that household, these people will be in the later survey with the same household identification number of the previous residents. Thus, matching households using household identification number and month of the survey would create false matches in some cases.

The only way to identify these cases and perfectly match the samples is to match individuals within household. Each member of the household receives the same household identification number and their own identification number. 
Table 2_Structure of interviews, Pesquisa Mensal de Emprego (PME)

\begin{tabular}{c|c|c|c|c}
$\ldots$ Month & Week 1 & Week 2 & Week 3 & Week 4 \\
\hline January & $\mathrm{A} 1$ & $\mathrm{~A} 2$ & $\mathrm{~A} 3$ & $\mathrm{~A} 4$ \\
\hline February & $\mathrm{B} 1$ & $\mathrm{~A} 2$ & $\mathrm{~A} 3$ & $\mathrm{~A} 4$ \\
\hline March & $\mathrm{B} 1$ & $\mathrm{~B} 2$ & $\mathrm{~A} 3$ & $\mathrm{~A} 4$ \\
\hline April & $\mathrm{B} 1$ & $\mathrm{~B} 2$ & $\mathrm{~B} 3$ & $\mathrm{~A} 4$ \\
\hline May & $\mathrm{B} 1$ & $\mathrm{~B} 2$ & $\mathrm{~B} 3$ & $\mathrm{~B} 4$ \\
\hline June & $\mathrm{C} 1$ & $\mathrm{~B} 2$ & $\mathrm{~B} 3$ & $\mathrm{~B} 4$ \\
\hline July & $\mathrm{C} 1$ & $\mathrm{C} 2$ & $\mathrm{~B} 3$ & $\mathrm{~B} 4$ \\
\hline August & $\mathrm{C} 1$ & $\mathrm{C} 2$ & $\mathrm{C} 3$ & $\mathrm{~B} 4$ \\
\hline September & $\mathrm{C} 1$ & $\mathrm{C} 2$ & $\mathrm{C} 3$ & $\mathrm{C} 4$ \\
\hline October & $\mathrm{A} 1$ & $\mathrm{C} 2$ & $\mathrm{C} 3$ & $\mathrm{C} 4$ \\
\hline November & $\mathrm{A} 1$ & $\mathrm{~A} 2$ & $\mathrm{C} 3$ & $\mathrm{C} 4$ \\
\hline December & $\mathrm{A} 1$ & $\mathrm{~A} 2$ & $\mathrm{~A} 3$ & $\ldots$ \\
\hline . $\ldots$ & $\ldots$ & $\ldots$
\end{tabular}

Source: Adapted from Bivar (1993).

However, matching using this approach would also create false matches because all or some members of the household might have moved out. Instead, it is necessary to use all the existent identification numbers (household and individual) and a series of demographic characteristics to perform the matching. I use sex, age, state of birth, position in the household and education attainment to match the pair of years. I allow some variation in age and education attainment to allocate changes over time and measurement problems, the other variables used are considered to be fixed over time.

Two shortcomings arise by using the PME: it only covers the main metropolitan areas of the country, and there is possible selection bias. However, over $30 \%$ of the Brazilian population lives in the metropolitan areas of the survey and these regions are highly representative of urban Brazil in terms of labor market and socioeconomic conditions. The second 
7 Peracchi and Welch (1994) use similar approach to examine labor force transition of older workers in the US. problem arises because the data will be composed by only those who were matched, as described before. Some individuals may not be matched because they move from that household during the year. Since I am dealing with older workers, it is possible that some have died. I checked for selectivity bias and observed that older individuals are more likely not to be matched. I also find that the percentage of matched households increased with time indicating an improvement in the quality of data over time; overall I had a $65 \%$ success rate in matching each pair of years.

\section{2_ Estimation Procedures}

I estimate retirement propensities in the PME by two approaches. First, using the unmatched data, I calculated age-specific stock of men in the labor force and retired in any given year and the risk of retirement derived. Second, using the matched sample, I use questions concerning the labor force status in two adjacent years to directly estimate the transition into retirement. ${ }^{7}$

I parameterize individual transition to retirement by using a probit specification. I concentrate my analysis on individual characteristics such as education, enrollment in the labor market (formal and informal), and previous occupation. These variables are used in several studies to predict retirement trends (Lumsdaine and Mitchell, 1999).

I estimate the retirement stock regressions using a limited number of variables that exist for workers in and out of the labor force (age and education). The retirement flow regressions are estimated based on a more extensive set of variables (for example, previous occupation, social security affiliation, earnings in the previous job, etc.).

$\operatorname{Probit}(p)=\beta_{0}+\beta_{i}^{*} X+\varepsilon_{j}$

Equation 1 represents the general probit model, where Probit ( $p i)$ represents the probability of being retired (or retiring), $X$ the matrix of explanatory variables and $\varepsilon_{j}$ is the error term.

Age is one of the most important variables in explaining retirement trends. I expect that older workers will have a higher propensity of retirement. If the social security scheme has an important impact on retirement decisions, I might observe higher retirement propensities around age 65 . 
Education also plays a role in retirement behavior. Education is highly correlated with income, wealth and type of job an individual holds. The net effect of education will reflect an income and substitution effects. The first creates incentives to retire since more educated workers are more able to afford retirement, while the latter implies a higher opportunity cost to leave work. Education also is related to the age workers entered the labor market. I assume that workers who invested less in human capital entered the labor force earlier and, normally, in more physically demanding jobs, which can play a role in the decision of whether to leave the labor force or not.

Occupation is related to the educational level but also to access to social security benefits. Workers in the formal market have more direct access to social security than workers in the informal sector and self-employed. Employers enroll workers in the formal market in the system while those in the informal sector have to decide on their own whether to join the pension system. This variable will give a good indication of the impacts of the pension system on the retirement propensities of workers in Brazil.
I estimate the model described in Equation 1 for males using pooled data for the period 1984 to 1999. I also estimated separate models for each year to check for consistency and stability over time. I estimated several nested models. The saturated model includes all possible explanatory variables and interaction terms. To assess the fit of the each model, I performed likelihood ratio tests on all alternative models. Comparing these values provides a method for assessing improvements in fit due to the inclusion of new model terms. However, most of the discussion is made using the model with best fit.

\section{Unmatched sample: results}

\section{1_Graphical Analysis}

Before turning to formal statistical analysis, I present graphical evidence that illustrates the changes in the retirement probability by age and over time. Figure 3 plots the probability of being retired by age-groups from 1983 to 1999 . Because retirement probabilities are difficult to illustrate for each age, I aggregate individual ages in five age-groups (48-50, 51-54, 55-60, 60-64, and 65 and over). 
Figure 3_ Time trend in the probability of being retired, males, Brazilian metropolitan areas, 1983-1999

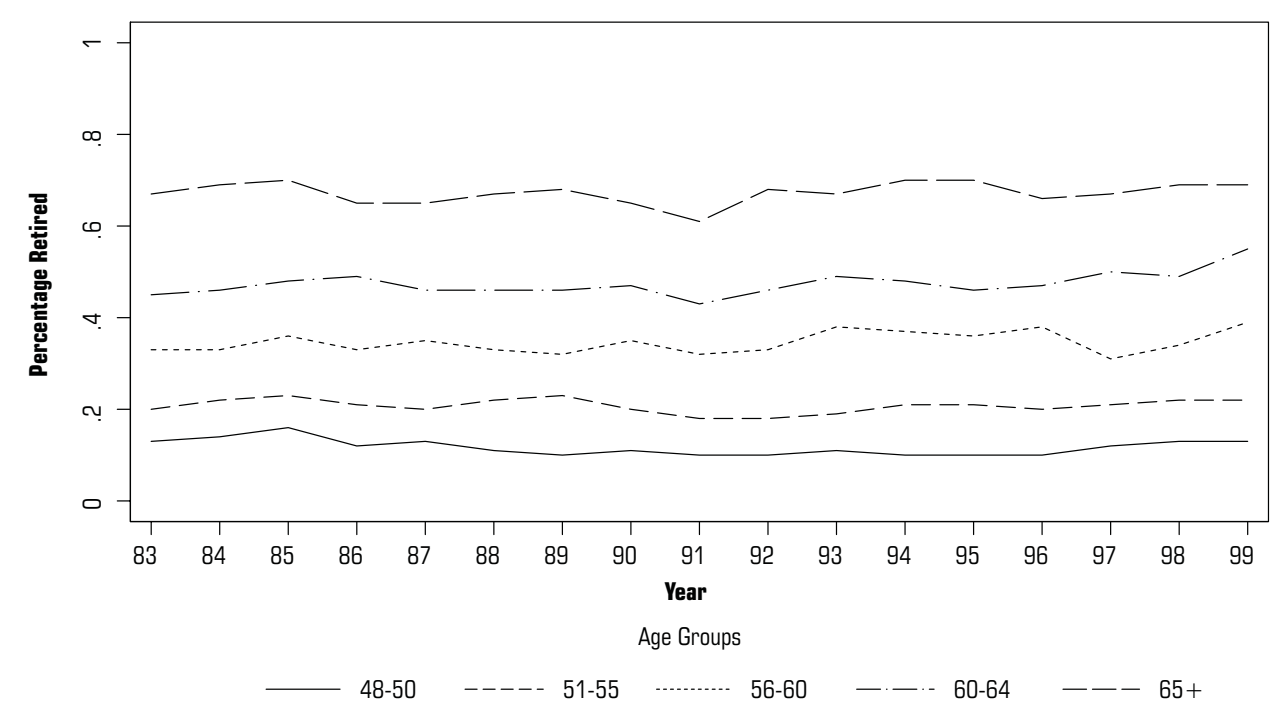

Source: PME, 1983-1999.

The figure shows a gradient in the probability of being retired by age. Surprisingly, there is no evidence of a strong time gradient, the percentage of older individuals retired only increases slightly by the end of the 1990 s. I interpret the non-existence of time gradient as an indication that the social security reforms of 1980s and 1990s did not affect retirement behavior of workers residing in the main metropolitan areas. Workers in those areas were already covered by the system, thus they did not benefit from the expansion in the late 1980s. Second, my data stop in 1999 and do not capture possible impacts of the 1998 reform.

Figure 4 compares the probability of being retired by age for sub-periods. Because retirement probabilities are difficult to illustrate for each year, I aggregate individual ages in two decades (1980s and 1990s). 
Figure 4_ Age profile of the probability of being retired by decade, males,

Brazilian metropolitan areas, 1983-1999

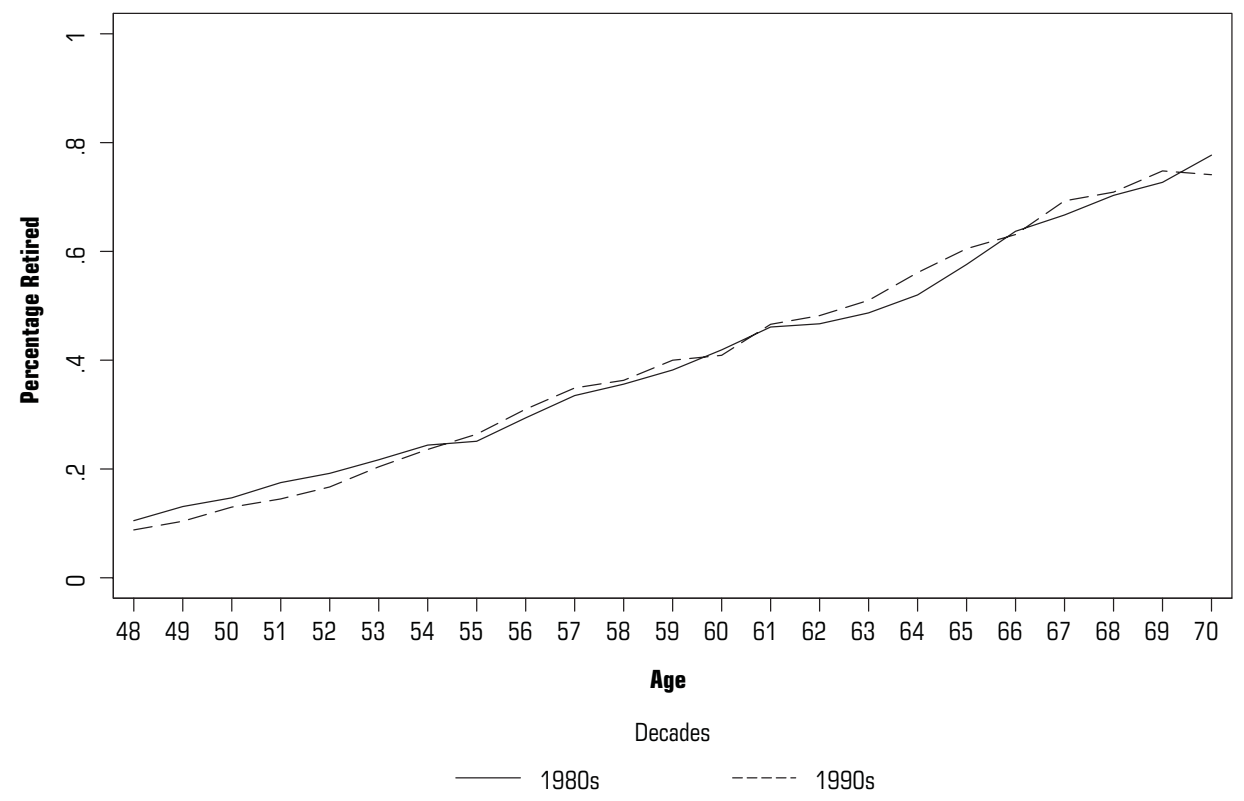

Source: PME, 1983-1999.

The figure shows that percentage of retirees increases monotonically with age. By age 65 about $70 \%$ of men considered themselves retired. It is striking, however, that among males aged 55 to 60 over $35 \%$ are retired, a number much greater than the United States, about 9\% (Gruber and Wise, 1999). As I show in the previous figure, the age-profiles do not vary much between decades. The figure, however, suggests that most of the elderly men in the metropolitan areas received pension benefits, and this percentage is extremely high even for those aged 60 and under. Figure 4 cannot be directly compared to Figure 2. The latter covers all regions of the country and includes both retirement and survival pension benefits while the former only includes those who respond being retired by the time of the survey. 


\section{2_Statistical Analysis}

Table 3 presents estimates of the probability of being retired by age. The probit specification is a reduced-form model of retirement behavior. My specification allows for most of the effects discussed before: monotonicity, differences in time-trends, and possible presence of business cycles. The parameters represent the marginal effects.

The dependent variable is a binary outcome (retired or not). All the covariates used in this analysis are categorical. They consist of a set of indicators for age, education (less 4 years, 5-8 years, 9-12 years, and $12+)$, region of residence and survey year. I also included interaction terms between age and time to capture possible differences in time trends at specific ages.

The estimates of age and time, in Table 3 confirm the main findings of the graphical analysis. In particular, there is strong evidence that the probability of being retired increases with age. In contrast, there is much less evidence of time trends in the probability of being retired, and of differences in timetrends at specific ages. None of the interaction terms between age and time are statically significant.

Education is a very important predictor of being retired. The relation between education and retirement appears to have an inverse- $\mathrm{U}$ shape. Workers with less education (0-4) and the more educated ones $(12+)$ have a lower probability of being retired compared to workers with medium and mediumhigh education. I interpret the existence of this gradient as an indication of lack of access to pension benefits (less educated ones) and type of occupation (more educated workers). People with some high-school or high-school graduates have better access to the public pension program, but also have more physically demanding occupations which might explain the higher prevalence of retirees in those groups.

Region of residence appears to be of minimal importance. The estimated parameters do not vary significantly across the six metropolitan areas. People with similar characteristics have similar chances of being retired whether they live in the south or northeast areas of the country. 
Table 3_ Results of Probit Model, Males, Brazil, 1984-1999 unmatched sample

\begin{tabular}{|c|c|c|c|c|c|}
\hline Variables & Model 1 & Model 2 & Model 3 & Model 4 & Model 5 \\
\hline \multicolumn{6}{|l|}{ Age } \\
\hline Continuous & & $0,4069 * * *$ & & & \\
\hline Age-Squared & & $-0,0064 * * *$ & & & \\
\hline Age-Cubic & & $0,0003^{* * *}$ & & & \\
\hline \multicolumn{6}{|l|}{ Age (cat.) } \\
\hline \multicolumn{6}{|l|}{48 (ref.) } \\
\hline 49 & $0,0319^{* * *}$ & & $0,0318^{* * *}$ & $0,031 * * *$ & $0,0321 * * *$ \\
\hline 50 & 0,0749 *** & & $0,0749 * * *$ & $0,0747 * * *$ & $0,0751^{* * *}$ \\
\hline 51 & $0,1201 * * *$ & & $0,1206^{* * *}$ & $0,1200^{* * *}$ & $0,1207^{* * *}$ \\
\hline 52 & $0,1568^{* * *}$ & & $0,1572 * * *$ & $0,1569 * * *$ & $0,1577^{* * *}$ \\
\hline 53 & $0,1953^{* * *}$ & & $0,1958^{* * *}$ & $0,1955^{* * *}$ & $0,1964 * * *$ \\
\hline 54 & $0,2316^{* * *}$ & & $0,2325^{* * *}$ & $0,2324 * * *$ & $0,2334 * * *$ \\
\hline 55 & $0,2630^{* * *}$ & & $0,2645^{* * *}$ & $0,2646^{* * *}$ & $0,2655^{* * *}$ \\
\hline 56 & $0,3012^{* * *}$ & & $0,3029 * * *$ & $0,3030^{* * *}$ & $0,3041 * * *$ \\
\hline 57 & $0,3341 * * *$ & & $0,3358^{* * *}$ & $0,3359 * * *$ & $0,3369^{* * *}$ \\
\hline 58 & $0,3588^{* * *}$ & & $0,3607 * * *$ & $0,3608^{* * *}$ & $0,3617^{* * *}$ \\
\hline 59 & $0,3926 * * *$ & & $0,3948^{* * *}$ & $0,3949 * * *$ & $0,3958^{* * *}$ \\
\hline 60 & $0,4109^{* * *}$ & & $0,4135^{* * *}$ & $0,4140^{* * *}$ & $0,4150^{* * *}$ \\
\hline 61 & $0,4505^{* * *}$ & & $0,4531 * * *$ & $0,4534 * * *$ & $0,4546^{* * *}$ \\
\hline 62 & $0,4703^{* * *}$ & & $0,4728^{* * *}$ & $0,4732^{* * *}$ & $0,4743^{* * *}$ \\
\hline 63 & $0,4891 * * *$ & & $0,4916^{* * *}$ & $0,4920^{* * * *}$ & $0,4929 * * *$ \\
\hline 64 & $0,5120^{* * *}$ & & $0,5145^{* * *}$ & $0,5148^{* * *}$ & $0,5158^{* * *}$ \\
\hline 65 & $0,5422^{* * *}$ & & $0,5446^{* * *}$ & $0,5453^{* * *}$ & $0,5463^{* * *}$ \\
\hline 66 & $0,5757^{* * *}$ & & $0,5784 * * *$ & $0,5788^{* * *}$ & $0,5797 * * *$ \\
\hline
\end{tabular}


Table 3_Results of Probit Model, Males, Brazil, 1984-1999 unmatched sample

(conclusion)

\begin{tabular}{|c|c|c|c|c|c|}
\hline Variables & Model 1 & Model 2 & Model 3 & Model 4 & Model 5 \\
\hline 67 & $0,5955^{* * *}$ & & $0,5980 * * *$ & $0,5988 * * *$ & $0,5994 * * *$ \\
\hline 68 & $0,6099 * * *$ & & $0,6124 * * *$ & $0,6132 * * *$ & $0,6138^{* * * *}$ \\
\hline 69 & $0,6215^{* * *}$ & & $0,6242^{* * *}$ & $0,6251 * * *$ & $0,6256^{* * *}$ \\
\hline 70 & $0,6269 * * *$ & & $0,6269 * * *$ & $0,6304 * * *$ & $0,6306^{* * *}$ \\
\hline \multicolumn{6}{|l|}{ Education } \\
\hline Low (ref.) Medium & & & $0,0441 * * *$ & $0,0426 * * *$ & $0,04176^{* * *}$ \\
\hline Medium-High & & & $0,0478 * * *$ & $0,0477 * * *$ & $0,04710^{* * *}$ \\
\hline High & & & $-0,0902 * * *$ & $-0,0917 * * *$ & $-0,0923^{* * *}$ \\
\hline Year Fixed Eff. & No & No & No & No & Yes \\
\hline Region Fixed Eff. & No & No & No & Yes & Yes \\
\hline $\begin{array}{l}\text { Number of Obs. } \\
\text { Note: }\left(^{* * *}\right) \text { sig. } 1 \% \text {; } \\
\left(^{* *}\right) \text { sig. } 5 \% \text {; } \\
\left(^{*}\right) \text { sig. } 10 \% \text {. Paramet }\end{array}$ & 396573 & $\begin{array}{l}396573 \\
. . .\end{array}$ & 396573 & 396573 & 396573 \\
\hline
\end{tabular}

Source: PME, 1983-1999.

\section{6_Matched sample: results}

\section{1_Graphical Analysis}

Before turning to formal statistical analysis, I present graphical evidence that illustrates retirement hazard rates in the urban metropolitan areas. Figure 5 plots the probability of retiring at each individual age from 1983 to 1999.

Surprisingly, because retirement hazard rates do not vary very much over the period of analysis I only show results of the pooled data.
In general, retirement hazard rates increase smoothly with age and there is no clear peak. In another article, I showed that for the whole population, hazard rates peak at age 60 and 65 . I interpret the non-existence of an age peak as an indicator that workers in the main metropolitan areas retire earlier, obtaining pension benefits via the Length of Service program. In any event, retirement hazard rates in the main metropolitan areas are very high. 
For example, at age $6531 \%$ of men who were in the labor force in year 1 were retired in year 2 . This rate is about fifteen percentage points higher than what is observed for the country as a whole, and seven percentage points higher than the US hazard rates (Costa, 1998). Peracchi and Welch (1994) find peaks at ages 62 (early-retirement age) and age 65 (normal retirement age) for the US. The hazard rate at age 65 is about $24 \%$, about seven percentage points lower than the hazard observed in Brazil metropolitan areas. In addition to that, whereas for the US rates are under $10 \%$ until age 60, in Brazil retirement hazard rate crosses $10 \%$ at age 55. The retirement hazard rates in Brazil are similar to those observed in Germany and Italy (Gruber and Wise, 1999). This finding indicates that Brazilian workers residing in the main metropolitan areas have better access to early retirement than workers living in other parts of the country, and the rates are as high as the ones observed in the US.

\section{Figure 5_Retirement hazard rates, males, Brazilian metropolitan areas, 1983-1999}

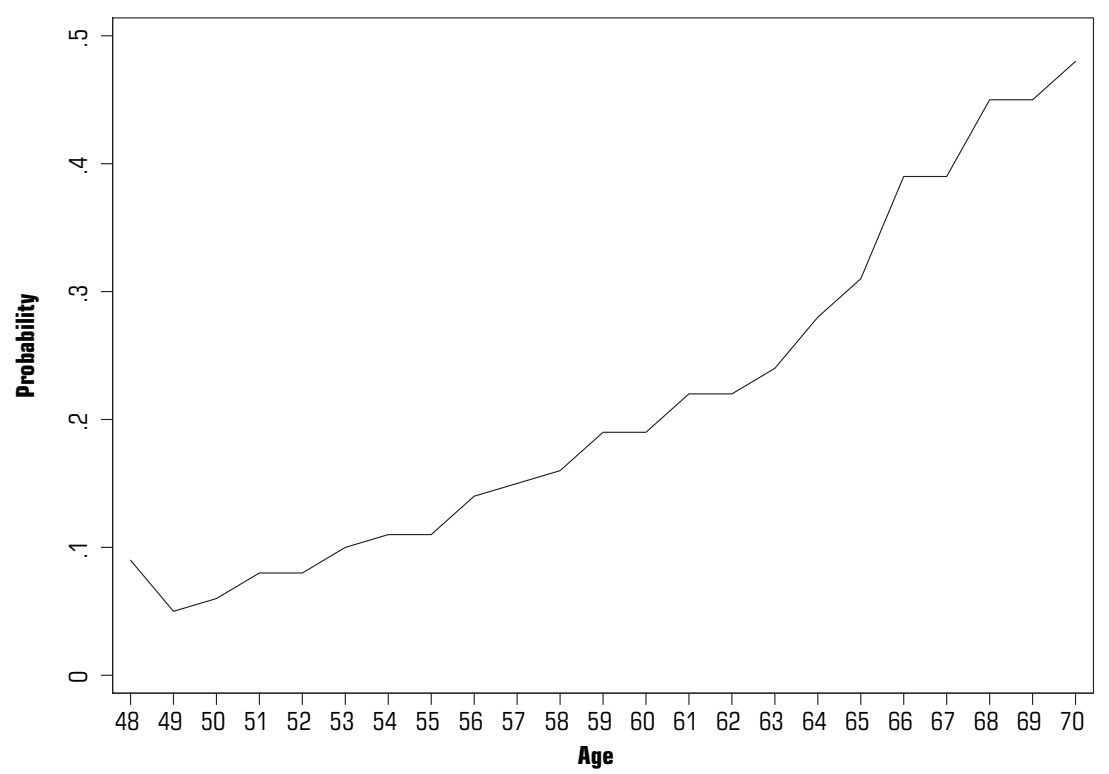

Source: PME, 1983-1999. 


\section{2_ Parameter Estimates}

In this section, I parameterize actual individual retirement probabilities across adjacent surveys. I am able to use a more extensive set of explanatory variables because I have direct information on labor force transitions over a 1 -year interval. I restrict my sample to individuals who were in the labor force in the first survey. Thus I have access to information about type of occupation, earnings, social security coverage, among others. ${ }^{8}$

Table 4 contains the estimated probit model for all variables included in the best and more parsimonious models. The dependent variable is a binary outcome constructed based on the labor force status of the individual in each survey year. The explanatory variables include a set of personal characteristics: age, time, age and time interactions, education, previous occupation, earnings in previous occupation, region of residence. In addition, I include variables to account for business cycle effects.

The parameters estimated from 8 The PME does not ask retired individuals questions about their previous occupation or income. measures a different outcome. The probability of being retired is a cumulative event, whereas the probability of retiring in a given year is more influenced by short-term events. In any event, the probabilities derived from the stock and flow approaches show similar general patterns and differentials.

The propensity of retiring increases monotonically with age when controlling for all other covariates. The direction and magnitude of the coefficients are the expected ones, with older men being more likely to retire than younger ones. The reasons are eligibility for social security benefits, decline in labor strength, and increased desire for leisure. I also investigated whether some ages are preferable to others for retirement. I also estimated a model using age as continuous variables and dummy indicators for ages 60 and 65. The coefficients for the two variables are very small and not statistically significant.

I find that previous employment status is a very important determinant of retirement probability in the main metropolitan areas. Self-employed and informal sector workers are less likely to retire than those in the formal sector. 
The formal sector employees have easier access to social security benefits.

Education seems to play an interesting role in the retirement decision of the population under study. More educated and less educated workers are less likely to retire than workers with medium levels of education. The price and substitution effects might be operating in different ways for the different set of workers.

Table 4_Results of Probit Model, Males, Brazil, 1984-1999 (matched sample. 66549 observations)

\begin{tabular}{|c|c|c|c|c|c|}
\hline Variables & Bivariate & Model 1 & Model 2 & Model 3 & Model 4 \\
\hline \multicolumn{6}{|l|}{ Age } \\
\hline Continuous & 0,01631 *** & $0,0163^{* * *}$ & $0,0166 * * *$ & $0,0164 * * *$ & $0,0168^{* * *}$ \\
\hline \multicolumn{6}{|l|}{ Age (cat.) } \\
\hline 55 & $-0,1042^{* * *}$ & $-0,052$ & & & \\
\hline 60 & $0,0399 * * *$ & 0,0084 & & & \\
\hline 65 & $0,1566^{* * *}$ & 0,0065 & & & \\
\hline \multicolumn{6}{|l|}{ Situation LM } \\
\hline Informal & $-0,04515^{* * *}$ & & $-0,0274 * * *$ & & $-0,028^{* * *}$ \\
\hline \multicolumn{6}{|l|}{ Education } \\
\hline Low & $0,01206^{* *}$ & & & $0,0105^{* *}$ & $-0,0034$ \\
\hline Medium & $0,02309 * * *$ & & & $0,0350^{* * *}$ & $0,0356^{* * *}$ \\
\hline Medium-High & $0,02619 * * *$ & & & $0,0384 * * *$ & $0,0357 * * *$ \\
\hline \multicolumn{6}{|l|}{ Sector Occ. } \\
\hline Industry & $-0,1030 * * *$ & & & & $0,0148^{* * *}$ \\
\hline GDP ( $\%$ a.a.) & $-0,1840 * * *$ & & & & $-0,1783^{* *}$ \\
\hline Unemployment & $0,011$. & & & & \\
\hline $\begin{array}{l}\text { **) } \\
\text { *) } \\
\text { *) } \\
\text { ) } \\
\text { sig. } 1 \% \% \\
\text { sig. } 10 \% \text {. Parame }\end{array}$ & t & & & & \\
\hline
\end{tabular}

Source: PME, 1984-1999. 


\section{7_Conclusion}

Longitudinal household data from Brazil are not readily available. Matched PME data allows for the construction of a long series of short panels and should be considered as an important source of information about the labor force transition of older workers.

Some of the patterns that I find are not surprising. For example, the probability of being retired increases monotonically with age and the strong dependence of labor force transition on other individual characteristics such as education. I also find that being in the formal sector of the labor market increases the probability of leaving the labor force at all ages. Some of the other patterns are more interesting and surprising.

First, the labor force participation of older workers in the main metropolitan areas is much lower than what is observed in the rest of the country. For example, the 2000 Brazilian census shows that about $50 \%$ of the individuals aged 65 in the country are in the labor force, but for those in the metropolitan areas less than $37 \%$ are in the labor force. The main explanation is that workers in the metropolitan areas had earlier enrollment into the social security program and have better access to early retirement by the length of service benefit.

Second, retirement hazard rates do not vary much over time, despite economic fluctuations over the past two decades (e.g. high inflation, low economic growth, long recession, high unemployment rate). I do not find any clear age peak, as in the case of the US. However, exit rates for individuals aged 60 and under are much higher than those observed in many developed countries (Gruber and Wise, 1999).

Third, I observe an inverse U-shaped relation between retirement and education. Less and more educated workers have similar retirement patterns during the period studied. This relation seems to be a combination of the type of occupation and the access to pension programs. Workers with a medium level of education are more likely to hold more physically demanding positions, and as their physical strength declines with age there is an increase in their transition out of the labor force.

In this paper, I do not investigate women's labor market transition. Female labor force participation and retirement behavior are harder to explain. The labor force participation of older 
women (65 and above) seems to be stable over time. The rapid increase in the labor force participation of younger women is impressive. As these women reach old age, they will have a much longer working history and job attainment, which might have significant impacts on retirement and the labor force participation of older women.

The impacts of increasing female labor force participation on demographic variables is an active area of research. Moreover, exploring how those changes impact the labor participation of their spouses, and consequent impacts to social security system, is an area of research that deserves more attention. 


\section{References}

ALÉM, Ana Cláudia; PASTORIZA, Florinda; GIAMBIAGI Fábio. A aposentadoria por tempo de serviço no Brasil: estimativa de subsídio recebido pelos seus beneficiários. Revista Brasileira de Economia, v. 52, p. 169-205, 1998.

BAKER, Michael; GRUBER, Jonathan; MILLIGAN, Kevin. The Retiremetn incentive effects of Canada's income security programs. Canadian Journal of Economics, v. 36, p. 261-290, 2003.

BARROS, Ricardo Paes de Barros; MENDONCA, Rosane; SANTOS, Daniel. Incidência e Naturezada Pobreza entre Idosos no Brasil. In: CAMARANO, Ana Amélia (Org.). Muito além dos 60: os novos idosos brasileiros. IPEA: Rio de Janeiro, 1999. p. 221-250.

BIVAR, Wasmalia. Aspectos da estrutura do desemprego no Brasil: composição por sexo e duração. 1993. Dissertação (Mestrado)

- Pontifícia Universidade Católica do Rio de Janeiro, Rio de Janeiro, 1993.

BONTURI, Marcos. The Brazilian pension system: recent reforms and challenges ahead. OECD

Working Paper n. 340, 2002.
BORSCH-SUPAN, Axel.

Incentive effects of social security on labor force participation: evidence in Germany and across Europe. Journal of Public Economics, v. 78, p. $25-49,2000$

BRASIL. Livro Branco da Previdência Social. Ministério da Previdência Social. 2002.

BRAVO, Jorge; UTHOFF, Andras. Costos fiscales de transicion y factores demograficos del cambio de sistemas de pension de reparto a capitalization. Celade Working Paper, 1998.

BRAZIL. Gasto social do governo central: 2001 e 2002. Ministério da Fazenda - Secretaria de Política Econômica, 2003

BURTLESS, Gary; QUINN, Joseph. Retirement trends and policies to encourage work among older Americans. In: BUDETTI, Peter; BURKHAUSER, Richard; GRAGORY, Janice; HUNT, H. Allan. (Ed.). Ensuring health and income security for an aging workforce. W. E. Upjohn Institute for Employment Research, 2001. p. 375-415.
CAMARGO, José Márcio. Política social no Brasil: prioridades erradas, incentivos perversos. São Paulo em Perspectiva, v. 18 , p. $68-77,2004$

\section{CARVALHO-FILHO, Irineu.}

Old-age benefits and retirement decisions of rural elderly in Brazil. 1999. Ph.D. thesis - Massachusets Institute of Technology, 1999.

COSTA, Dora. The evolution of retirement: an American economic history, 1880-1990. The University of Chicago Press, 1998.

GIAMBIAGI, Fábio; ALÉM, Ana Cláudia Duarte de. $A$ despesa previdenciária no Brasil: evolução, diagnóstico e perspectivas. Rio de Janeiro: BNDES, 1997. (Textos para discussão, 57).

GIAMBIAGI, Fábio; CASTRO, Lavínia Barros de. Previdência social: diagnósticos e propostas de reforma. Revista do BNDES, v. 10, p. $265-292,2003$

GRUBER, Jonathan; WISE, David (Eds.). Social security and retirement around the world. The University of Chicago Press, 1999.
GRUBER, Jonathan; WISE, David. Social security programs and retirement around the world: microestimation. 2002. (NBER Working Paper, n. 9407).

HURD, Michael. Research on the elderly: economic status, retirement, and consumption and saving. Journal of Economic Literature, v. 28, p. 565-637, 1990.

IPUMS. Integrated Public Use Microdata Series. 2005.

$<$ www.ipums.org>

JOHNSON, Richard. The effect of old-age insurance on male retirement: evidence from historical cross-country data. 2000. (Working paper).

LEITE, Celso Barroso.

Um século de previdência social. Zahar Editores, 1983.

KRUEGER, Alan; PISCHKE; Jorn-Steffen. The effect of social security on labor supply: a cohort analysis of the notch generation. Journal of Labor Economics, v. 10, p. 412-437, 1992

LAM, David; LEIBBRANDT, Murray; RANCHHOD, Vimal. Labor force withdrawal of the elderly in South Africa. International Conference of the IUSSP, 2005. 
LEGRAND, Thomas. The determinants of men's retirement behavior in Brazil. The Journal of Development Studies, v. 31, p. 673-701, 1995.

LIBERATO, Vânia Cristina. $A$ oferta de trabalho masculina 'pós-aposentadoria' Brasil Urbano1981/2001. 2003. Dissertação

(Mestrado em Demografia) -

Faculdade de Ciências

Econômicas, Universidade

Federal de Minas Gerais, Belo Horizonte, 2003.

LUMSDAINE, Robin; MITCHELL, Olivia. New developments in the economic analysis of retirement. In: Ashenfelter, O.; CARD, D. (Ed.). Handbook of Labor Economics. Elsevier Science, 1999. v. 3 , chapter 49, p. 3261-3307.

MEDICI, André. The political economy of reform in Brazil's civil servant pension scheme.

Inter-American Development Bank, 2002. (Technical report).

ORNELAS, Waldeck; VIEIRA Solange. Novo rumo da previdência brasileira. Revista do BNDES, v. 6, p. 31-48, 1999.

PERACCHI, Franco; WELCH, Finis. Trends in labor force transitions of older men and women. Journal of Labor Economics, v. 12, p. 210-242, 1994.

PME - Pesquisa Mensal de Emprego (1993-1999) microdados.
PROFETA, Paola. Aging and retirement: evidence across countries. International Tax and Public Finance, v. 9, p. 651-672, 2002.

QUINN, Joseph;

BURKHAUSER, Richard. retirement and labor force behavior of the elderly. In: PRESTON, Samuel, Martin, LINDA. (Ed.). Demography of Aging. National Academy Press, 1994. p. 50-101.

SILVA LEME, Maria Carolina da; MÁLAGA, Tomás. Entrada e saída precoce da forca de trabalho: incentivos do regime de previdência brasileiro. Revista Brasileira de Economia, v. 55, p. 205-222, 2001.

STEPHANES, Reinhold. Reforma da previdência. Record, 1998.

SVEINBJORN, Blondal; SCARPETTA, Stefano.

The retirement decision in $O E C D$ countries. OECD - Economics Department, 1998.

(Working Paper, 202).

TURRA, Cássio; QUEIROZ, Bernardo. Before it's too late: demographic transition, labor supply, and social security problems in Brazil. In: United Nations Expert Group Meeting on Social and Economic Implications of Changing Population Age Structures. United Nations, 2005.

WISE, David. Social security provisions and the labor force participation of older workers. Population and Development Review, n. $30,2004$.
:This paper is an adaptation of : Chapter 6 of my Ph.D.

: dissertation. Financial support - from Capes Foundation is - thankefully acknowledge. I am - grateful to my advisor Ronald D.

:Lee for his comments during

- different stages of this project.

: Participants at the Department : of Demography Brown-Bag - seminar also deserve thanks for - their comments in preliminary - versions of the paper.

'Author's e-mail

lanza@cedeplar.ufmg.br

Artigo recehido em janeiro de 2006

- aprovado em outubro de 2006. 